\title{
Erratum to: Reactive oxygen species mediated improvement in vigour of static and pulsed magneto-primed cherry tomato seeds
}

\author{
Mukesh Kumar Gupta $^{1}$ - Anjali Anand ${ }^{1} \cdot$ Vijay Paul $^{1} \cdot$ Anil Dahuja $^{2}$ \\ A. K. Singh ${ }^{3}$
}

Published online: 26 July 2015

(C) Indian Society for Plant Physiology 2015

\begin{abstract}
Seed priming with magnetic field was used to improve germination, vigour and yield in cherry tomato seeds. Cherry tomato seeds were magneto-primed with various doses of static magnetic field (SMF) in the range of 50-150 milliTesla $(\mathrm{mT})$ for duration of $30 \mathrm{~min}$ and $1 \mathrm{~h}$. SMF dose of $100 \mathrm{mT}$ for $30 \mathrm{~min}$ gave maximum increase in germination characteristics and was selected for application as pulsed dose. Seeds were exposed to pulsed magnetic field (PMF) dose in the cycles of 2, 3, 5 or 6 min on and off where PMF dose of $3 \mathrm{~min}$ on and off cycle showed substantial enhancement of $23 \%$ in seedling vigour compared to other treatments. Superoxide ion and hydrogen peroxide contents increased by two fold in static and pulsed magneto-primed seeds. Antioxidant enzymes system revealed increased superoxide dismutase activity and oxidative reaction of peroxidase resulted in production of hydrogen peroxide during germination of magnetoprimed seeds. Increased ascorbate peroxidase activity during initial stages and catalase at later stages of
\end{abstract}

The online version of the original article can be found under doi:10. 1007/s40502-015-0161-8.

Erratum to: Ind J Plant Physiol.doi:10.1007/s40502-015-0161-8. The original article has been published with incorrect figures. The full corrected article is republished on the following pages and should be treated as definitive by the reader, replacing the earlier version.

Anjali Anand

anjaliiari@gmail.com

1 Division of Plant Physiology, Indian Agricultural Research Institute, New Delhi 110 012, India

2 Division of Biochemistry, Indian Agricultural Research Institute, New Delhi 110 012, India

3 Division of Horticulture, Indian Agricultural Research Institute, New Delhi 110 012, India germination helped in scavenging of hydrogen peroxide in germinating magneto-primed seeds. PMF treated seeds showed better response in terms of invigoration and reactive oxygen species related parameters than static magnetoprimed seeds. Both static and pulsed magneto-primed seeds were evaluated for their field performance. Yield increased by $17 \%$ in SMF and $27 \%$ in plants from PMF primed seeds. There was no major change in the number of fruits and the increase in yield was mainly due to a substantial increase in weight per fruit, which was 7.76 and $8.55 \mathrm{~g}$ in SMF and PMF, respectively as compared to $6.4 \mathrm{~g}$ in control. Fruit quality was also better in primed compared to control seeds. Our results indicated that pulsed magnetopriming is more effective in dry seed priming treatment for seed invigoration in cherry tomatoes.

Keywords Antioxidant enzyme $\cdot$ Cherry tomato $\cdot$ Pulsed magneto-priming $\cdot$ Reactive oxygen species $\cdot$ Seed germinability $\cdot$ Static magneto-priming $\cdot$ Vigour

\section{Introduction}

Cherry tomato (Lycopersicon esculentum L.) is a small garden variety of tomato that has very high nutritive value, containing vitamin A, lycopene, beta-carotene, vitamin C and minerals like calcium, potassium etc. Crop yields of vegetable crops can be maximized by establishment of an adequate and uniform plant stand. Rapid and uniform field emergence of seedlings is therefore, a challenge as slow emergence results in smaller plants and seedlings, which are more vulnerable to soil-borne diseases thus leading to decline in productivity.

Seed priming is a physiological seed enhancement method for overcoming poor and erratic seed germination 
in many vegetable and flower species. Seed priming techniques, like hydro-priming, osmo-priming, solid-matrix priming and halo-priming have been experimented extensively to increase the speed and synchrony of seed germination in vegetable and field crops (Nakaune et al. 2012). Pre-sowing seed treatment with magnetic field called "magneto-priming" is a dry seed priming technique that doesn't hydrate the seed, allows storage of the seed at room temperature and is eco-friendly. Other priming treatments have a mandatory requirement of dehydrating the seed for storage before sowing but magneto-priming is carried out in dry seed and has proved to be more useful. Several researchers have reported the beneficial effect of both static and pulsed magnetic field (PMF) in different plant species (Radhakrishnan and Ranjithakumari 2012; Bilalis et al. 2013). ROS play a key signaling role in the achievement of major events of seed life, such as germination or dormancy release. ROS such as superoxide radicals $\left(\mathrm{O}_{2}{ }^{-}\right)$, hydrogen peroxide $\left(\mathrm{H}_{2} \mathrm{O}_{2}\right)$ and hydroxyl radicals $(\mathrm{OH} \cdot)$ are generated as a result of aerobic metabolism in mitochondria, peroxisomes and the apoplastic space in the germinating seeds. For ROS to act as cellular messengers, seeds have evolved specific ROS removing mechanisms to protect against the over production of ROS. The stimulation in seedling growth due to magneto-priming is mediated through the production of ROS in the germinating soybean seed (Shine et al. 2012). Increased level of free radicals in seeds after treatment of seeds with laser light and magnetic field accompanied by enhanced dynamics of seed germination have also been reported in faba bean and pea seeds (Podlesny et al. 2005). Thus the present study was conducted to (i) optimize the static and PMF dose for seed invigoration and (ii) to deduce a relationship between the ROS homeostasis maintained by antioxidative metabolism during germination in static and pulse magneto-primed cherry tomato seeds.

\section{Materials and methods}

\section{Seed magneto-priming}

An electromagnetic field generator "Testron EM-60" with variable magnetic field strength (50-300 mT) with a gap of $10 \mathrm{~cm}$ between pole pieces was used for seed treatment. Cherry tomato seeds (Selection 1) were exposed to static magnetic field (SMF) of $50-150 \mathrm{mT}$ in increments of $50 \mathrm{mT}$ for varying durations of $30 \mathrm{~min}$ and $1 \mathrm{~h}$, by placing in a cylindrical-shaped sample holder of $42 \mathrm{~cm}^{3}$ capacity, made of a non-magnetic thin transparent plastic sheet. For parallel control, seeds from the same lot used for magnetic field exposure were kept under conditions which had no influence of the induced magnetic field. The field strength and duration was standardized for maximum enhancement of germination and vigor under laboratory conditions and best combination was identified for standardization in the pulsed mode.

Among all the treatments in the static mode, $100 \mathrm{mT}$ for 30 min was most effective in enhancing the germination parameters in magneto-primed seeds and was further employed for treating seeds in pulsed mode. Four pulsed doses (the number of times the sample was exposed to magnetic field in $30 \mathrm{~min}$ ) were designed for PMF treatment with $100 \mathrm{mT}(30 \mathrm{~min})$ applied in the cycle of 2, 3, 5 or 6 min on and off.

\section{Germination-percentage}

Seed germination was determined by using "between papers" method given by ISTA rules (ISTA 1985). Hundred seeds in four replications of 25 seeds each were placed between two layers of moist germination papers. The germination papers were rolled carefully ensuring that no excess pressure was placed on the seeds. These were wrapped in a sheet of wax paper to reduce surface evaporation of moisture and placed in the germination incubator at $25{ }^{\circ} \mathrm{C}$ in an upright position. After 14 days, seeds were evaluated for normal, abnormal seedling, un-germinated and dead seeds.

\section{Rate of germination}

Seeds were placed in Petri dish on a double layer of moistened filter paper and incubated in darkness in a germinator at $25{ }^{\circ} \mathrm{C}$. A daily germination count of the incubated seeds was taken until no more seeds germinated, and the speed of germination was calculated following Maguire (1962) as

Speed of germination $=\sum(\mathrm{n} / \mathrm{t})$

where $\mathrm{n}=$ number of seeds germinated and $\mathrm{t}=$ time of count.

$$
\begin{aligned}
\sum(\mathrm{n} / \mathrm{t})= & \frac{\text { Number of seeds germinated }}{\text { Day of the first count }}+\cdots \\
& +\frac{\text { Number of seeds germinated }}{\text { Day of the final count }}
\end{aligned}
$$

\section{Seedling growth and vigour indices}

Ten normal seedlings from each replicate kept for germination, were randomly identified to measure shoot and root length in $\mathrm{cm}$. They were subsequently dried at $80{ }^{\circ} \mathrm{C}$ in an oven and weighed together till a constant weight was obtained. 
Seedling vigour was calculated following Abdul-Baki and Anderson (1973) as

$$
\begin{aligned}
\text { Vigour index I }= & \text { Germination } \% \\
& \times \text { Seedling length }(\text { Root }+ \text { Shoot })(\mathrm{cm})
\end{aligned}
$$

VigourindexII $=$ Germination $\%$

$$
\times \text { Seedling dry weight }(\text { Root }+ \text { Shoot })(g)
$$

\section{Determination of superoxide $\left(\mathrm{O}_{2}{ }^{-}\right)$}

Superoxide free radical was quantified by its capacity to reduce nitroblue tetrazolium chloride (NBT) in primed and unprimed seeds following the method of Chaitanya and Naithani (1994). Seeds (40 mg) were homogenized in $2 \mathrm{ml}$ of pre cooled phosphate buffer $(0.2 \mathrm{M}, \mathrm{pH} 7.2)$. The homogenate were centrifuged at $10,000 \times g$ for $10 \mathrm{~min}$ at $4{ }^{\circ} \mathrm{C}$. Supernatant was used for estimation of superoxide radical. A $3 \mathrm{ml}$ reaction mixture contained $100 \mu \mathrm{l}$ supernatant in $0.75 \mathrm{mM}$ NBT, $25 \mathrm{mM}$ sodium carbonate, $0.1 \mathrm{mM}$ EDTA and $13.3 \mathrm{mM}$ L-methionine. Reaction mixture was incubated at $30^{\circ} \mathrm{C}$ in a water bath for $10 \mathrm{~min}$ and the absorbance was recorded at $540 \mathrm{~nm}$ in a spectrophotometer. Superoxide radical content was calculated using a molar absorption coefficient of $12.8 \mathrm{mM}^{-1} \mathrm{~cm}^{-1}$ and expressed as $\mu \mathrm{mol} \mathrm{g}^{-1}$ fr. wt.

\section{Determination of hydrogen peroxide $\left(\mathrm{H}_{2} \mathrm{O}_{2}\right)$}

Hydrogen peroxide was estimated by formation of titanium-hydro peroxide complex (Mukherjee and Choudhari 1983). Seeds (40 mg) were ground in $3 \mathrm{ml}$ cooled acetone in a chilled mortar and pestle kept in ice bucket. The homogenate was filtered through Whatman No. 1 filter paper followed by addition of $2 \mathrm{ml}$ of titanium reagent and $2.5 \mathrm{ml}$ of ammonium hydroxide solution to precipitate the titanium-hydro peroxide complex. The reaction mixture was centrifuged at $10,000 \times g$ for $10 \mathrm{~min}$. The precipitate was dissolved in $5 \mathrm{ml}$ of $2 \mathrm{M}$ concentrated sulphuric acid and re-centrifuged. The supernatant was read at $415 \mathrm{~nm}$ against blank and $\mathrm{H}_{2} \mathrm{O}_{2}$ was expressed as $\mu \mathrm{mol} \mathrm{H}_{2} \mathrm{O}_{2} \mathrm{~g}^{-1}$ fr. wt.

\section{Enzyme extraction}

Samples (40 mg) were crushed into a fine powder in a mortar and pestle with liquid nitrogen. Soluble protein was extracted by homogenizing the powder in $2 \mathrm{ml}$ of $50 \mathrm{mM}$ potassium phosphate buffer $(\mathrm{pH} 7.0)$ containing $1 \mathrm{mM}$ EDTA and $1 \%(\mathrm{w} / \mathrm{v})$ polyvinylpyrrolidone, with the addition of $0.2 \mathrm{mM}$ ascorbate in case of ascorbate peroxidase assay. The homogenate was centrifuged at $10,000 \times g$ for
$30 \mathrm{~min}$ at $4{ }^{\circ} \mathrm{C}$ and the supernatant was used for the following assays.

\section{Superoxide dismutase (SOD) activity}

Superoxide dismutase activity (SOD) was assayed by monitoring the inhibition of photochemical reduction of NBT (Dhindsa et al. 1981). The $3 \mathrm{ml}$ reaction mixture contained $50 \mathrm{mM}$ potassium phosphate buffer $(\mathrm{pH} 7.8)$, $13 \mathrm{mM}$ methionine, $25 \mathrm{mM}$ NBT, $2 \mu \mathrm{M}$ riboflavin, $0.1 \mathrm{mM}$ EDTA, $50 \mathrm{mM}$ sodium carbonate and $0.1 \mathrm{ml}$ enzyme extract. The reaction mixture was illuminated for $15 \mathrm{~min}$ at a light intensity of 3600 lux. One unit of SOD was defined as the amount of enzyme required for causing $50 \%$ inhibition of the reduction of NBT as monitored at $560 \mathrm{~nm}$.

\section{Peroxidase (POX) activity}

Peroxidase activity (POX) was measured by monitoring the formation of tetraguaiacol (extinction coefficient $26.6 \mathrm{mM}^{-1} \mathrm{~cm}^{-1}$ ) from guaiacol (Rao et al. 1996). The POX reaction solution $(3 \mathrm{ml})$ contained $0.5 \mathrm{mM}$ phosphate buffer (pH 6.1), $16 \mathrm{mM}$ guaiacol, $2 \mathrm{mM} \mathrm{H}_{2} \mathrm{O}_{2}$ and $20 \mu \mathrm{l}$ enzyme extract. Changes in absorbance of the reaction solution at $470 \mathrm{~nm}$ were determined every $30 \mathrm{~s}$ using UVvisible spectrophotometer.

\section{Catalase (CAT) activity}

Catalase activity (CAT) was determined by following the consumption of $\mathrm{H}_{2} \mathrm{O}_{2}\left(\varepsilon=39.4 \mathrm{mM}^{-1} \mathrm{~cm}^{-1}\right)$ at $240 \mathrm{~nm}$ absorbance for $3 \mathrm{~min}$ (Aebi 1984). The reaction mixture contained $50 \mathrm{mM}$ phosphate buffer ( $\mathrm{pH} 7.0$ ), $10 \mathrm{mM} \mathrm{H}_{2} \mathrm{O}_{2}$ and $0.1 \mathrm{ml}$ of enzyme extract in a volume of $3 \mathrm{ml}$.

\section{Ascorbate peroxidase (APOX) activity}

The ascorbate peroxidase activity was estimated by recording the decrease in absorbance at $290 \mathrm{~nm}$ $\left(\varepsilon=2.8 \mathrm{mM}^{-1} \mathrm{~cm}^{-1}\right.$ ) for $1 \mathrm{~min}$ in $3 \mathrm{ml}$ reaction mixture containing $50 \mathrm{mM}$ potassium phosphate buffer $(\mathrm{pH} \mathrm{7.0)}$, $0.5 \mathrm{mM}$ ascorbic acid, $0.1 \mathrm{mM}$ EDTA, $1.5 \mathrm{mM} \mathrm{H}_{2} \mathrm{O}_{2}$ and $0.1 \mathrm{ml}$ enzyme extract. The reaction was started by adding the enzyme extract. Correction was done for the low, non enzymatic oxidation of ascorbic acid by $\mathrm{H}_{2} \mathrm{O}_{2}$ (Nakano and Asada 1981).

\section{Glutathione reductase (GR) activity}

Glutathione reductase (GR) assay was based on the formation of red coloured complex by reduced glutathione with 5,5-dithiobis-2-nitrobenzoic acid (DTNB) (Smith 
et al. 1998). The reaction mixture contained $10 \mathrm{mM}$ potassium phosphate buffer, $0.33 \mathrm{mM}$ EDTA, $0.5 \mathrm{mM}$ DTNB, $2.0 \mathrm{mM}$ NADPH, $20 \mathrm{mM}$ GSSG (oxidized glutathione), $0.1 \mathrm{ml}$ of enzyme extract and double distilled water to make up the final volume to $3.0 \mathrm{ml}$. Reaction was started by adding $0.1 \mathrm{ml}$ of $20 \mathrm{mM}$ GSSG (oxidized glutathione). Increase in absorbance at $412 \mathrm{~nm}$ was recorded in UV-visible spectrophotometer (Systronics, India).

\section{Total soluble solids and lycopene content of fruit}

Tomato juice was extracted from red ripe fruits, and a drop of juice was placed over the prism of hand refractometer (Digital ATAGO, Sanco, Japan). Total soluble solids recorded were averaged over three fruits separately. The total lycopene content in tomato fruit was estimated spectrophotometrically at $503 \mathrm{~nm}$ following the method of Thimmaiah (1999) and expressed as mg lycopene $100 \mathrm{~g}^{-1}$ fresh weight of tomato.

\section{Statistical analysis}

The data obtained from germination parameters are expressed as mean \pm S.E.M. of four replicates of 25 seeds each. As the experimental design was completely randomized design, the data were analyzed by two way analysis of variance (ANOVA) using the software OPSTAT. Least significant difference was calculated for each trait at a probability level of $\mathrm{P}<0.05$. Values for all enzyme activities are means of three replicates.

\section{Results and discussion}

\section{Germination and vigour indices}

The results of optimization studies for improving seed vigour with static and PMF exposure are presented in Tables 1 and 2, respectively. SMF field exposure did not result in any significant change in the germination parameters of cherry tomatoes although SMF dose of $100 \mathrm{mT}$ (30 $\mathrm{min})$ showed $15 \%$ increase in rate of germination compared to un-primed control (Table 1). On the basis of marginal increase observed for most of the germination characters under SMF exposure, $100 \mathrm{mT}$ (30 min) was given as pulsed dose for 2, 3, 5, 6 min to cherry tomato seeds. Though germination percentage was not significantly affected, there was $6 \%$ increase at PMF ( 3 min on/ off) dose (Table 2). Rate of germination showed insignificant increase by $8-16 \%$ at lower SMF dose of 50-100 mT for different durations. The $100 \mathrm{mT}(30 \mathrm{~min})$ static dose when applied as pulsed dose for 2, 3, 5, $6 \mathrm{~min}$ showed the maximum increase $(21 \%)$ in rate of germination at $3 \mathrm{~min}$ on and off pulse in comparison to untreated control (Table 2).

Static magnetic field exposed seeds did not show a significant change in root length but shoot length was significantly higher, which increased by $9-20 \%$ at different doses of SMF compared to untreated control (Table 1). On the other hand, PMF treatment showed a notable increase in root length. Root and shoot length increased by 21 and $18 \%$, respectively at PMF (3 min on and off) (Table 2). Dry weight of ten randomly identified seedlings increased by $13 \%$ in SMF dose of $100 \mathrm{mT}$ (30 min) compared to unprimed control. Similarly, a $19 \%$ increase in seedling dry weight was observed in PMF dose applied in 3 min pulses.

The SMF strength and its duration had positive effect on vigor indices. Seeds treated with $100 \mathrm{mT}$ (30 min) recorded the highest increase of $24 \%$ in vigor index I and $37 \%$ in vigor index II (Table 1). On the other hand, PMF (3 min on and off) resulted in 20 and $23 \%$ increase in Vigour Index I and II, respectively over the untreated control (Table 2).

Based on the results of all the germination related characteristics tested in Static and Pulsed magneto-primed and un-primed seeds, SMF dose of $100 \mathrm{mT}(30 \mathrm{~min})$ and PMF dose of $100 \mathrm{mT}$ (30 min) applied as $3 \mathrm{~min}$ on and off cycle were identified for evaluation of biochemical changes in the germinating seed and field performance of the crop.

\section{Superoxide ion and hydrogen peroxide content}

Superoxide ion production was high in both the magnetic treatments compared to control (Fig. 1A). Approximately two fold increase was observed in both the treatments at the initial stage of imbibition. A more than twofold increase was observed in PMF treated seeds after $12 \mathrm{~h}$ of imbibition compared to unprimed control. SMF treated seeds also recorded higher levels of hydrogen peroxide than control albeit to a lesser extent in the range of 29-41\% between 12 and $36 \mathrm{~h}$ of imbibition (Fig. 1B). The ability of seeds to germinate has been linked to the accumulation of a critical level of $\mathrm{H}_{2} \mathrm{O}_{2}$, as this molecule is produced at a higher level in non-dormant imbibed seeds than in dormant imbibed seeds (Bailly et al. 2008). Report on the positive role of ROS in seeds show that superoxide radical and $\mathrm{H}_{2} \mathrm{O}_{2}$ act as secondary messengers in seed germination process (Barba-Espin et al. 2011). An "oxidative window" for ROS ensures that germination proceeds at a faster rate helping in establishment of more vigorous seedling in magneto-primed seeds. The levels of free radicals in magneto-primed cherry tomato seeds that have a promotive effect on germination, with their 
Table 1 Effect of static magnetic field on germination characteristics of cherry tomato

\begin{tabular}{llllllll}
\hline Magnetic field dose & Germination $\%$ & $\begin{array}{l}\text { Root length } \\
(\mathrm{cm})\end{array}$ & $\begin{array}{l}\text { Shoot length } \\
(\mathrm{cm})\end{array}$ & $\begin{array}{l}\text { Seedling dry } \\
\text { wt. }(\mathrm{mg})\end{array}$ & $\begin{array}{l}\text { Vigour } \\
\text { index I }\end{array}$ & $\begin{array}{l}\text { Vigour } \\
\text { index II }\end{array}$ & $\begin{array}{l}\text { Rate of } \\
\text { germination } \\
(\text { no. day }\end{array}$ \\
\hline $50 \mathrm{mT}(30 \mathrm{~min})$ & $72.0 \pm 5.89$ & $4.20 \pm 0.21$ & $12.24 \pm 0.22$ & $5.40 \pm 0.92$ & $1184.20 \pm 97.18$ & $0.402 \pm 0.087$ & $19.70 \pm 0.32$ \\
$50 \mathrm{mT}(1 \mathrm{~h})$ & $77.0 \pm 5.00$ & $4.00 \pm 0.24$ & $11.58 \pm 0.36$ & $6.25 \pm 0.96$ & $1202.93 \pm 80.43$ & $0.484 \pm 0.085$ & $20.50 \pm 0.08$ \\
$100 \mathrm{mT}(30 \mathrm{~min})$ & $79.0 \pm 1.00$ & $4.23 \pm 0.34$ & $11.30 \pm 0.33$ & $6.12 \pm 0.36$ & $1222.99 \pm 48.59$ & $0.485 \pm 0.033$ & $21.20 \pm 0.75$ \\
$100 \mathrm{mT}(1 \mathrm{~h})$ & $76.0 \pm 2.83$ & $3.90 \pm 0.28$ & $11.37 \pm 0.17$ & $5.80 \pm 0.32$ & $1160.88 \pm 67.21$ & $0.442 \pm 0.037$ & $16.03 \pm 1.14$ \\
$150 \mathrm{mT}(30 \mathrm{~min})$ & $73.0 \pm 2.49$ & $3.69 \pm 0.19$ & $11.09 \pm 0.37$ & $5.82 \pm 0.35$ & $1085.13 \pm 96.56$ & $0.415 \pm 0.025$ & $17.64 \pm 1.30$ \\
$150 \mathrm{mT}(1 \mathrm{~h})$ & $78.0 \pm 3.46$ & $4.20 \pm 0.09$ & $11.13 \pm 0.34$ & $4.95 \pm 0.35$ & $1202.12 \pm 64.47$ & $0.388 \pm 0.040$ & $21.00 \pm 0.82$ \\
Control & $74.0 \pm 4.46$ & $3.42 \pm 0.11$ & $10.20 \pm 0.36$ & $4.87 \pm 0.34$ & $984.61 \pm 47.64$ & $0.380 \pm 0.023$ & $18.35 \pm 1.20$ \\
LSD (P < 0.05) & $\mathrm{NS}$ & $\mathrm{NS}$ & 0.946 & $\mathrm{NS}$ & $\mathrm{NS}$ & $\mathrm{NS}$ & 3.114 \\
\hline
\end{tabular}

Table 2 Effect of pulsed magnetic field on germination characteristics of cherry tomato

\begin{tabular}{llllllll}
\hline Magnetic field dose & Germination $\%$ & $\begin{array}{l}\text { Root length } \\
(\mathrm{cm})\end{array}$ & $\begin{array}{l}\text { Shoot length } \\
(\mathrm{cm})\end{array}$ & $\begin{array}{l}\text { Seedling dry } \\
\text { wt. (mg) }\end{array}$ & $\begin{array}{l}\text { Vigour } \\
\text { index I }\end{array}$ & $\begin{array}{l}\text { Vigour } \\
\text { index II }\end{array}$ \\
\hline PMF (2 min) & $73.0 \pm 5.00$ & $3.39 \pm 0.15$ & $10.39 \pm 0.65$ & $7.60 \pm 0.59$ & $\begin{array}{l}\text { Rate of } \\
\text { germination } \\
(\text { no. day }\end{array}$ \\
PMF (3 min) & $75.0 \pm 7.19$ & $4.12 \pm 0.14$ & $10.31 \pm 0.29$ & $9.07 \pm 1.06$ & $1169.73 \pm 14.85$ & $0.660 \pm 0.04$ & $24.35 \pm 0.43$ \\
PMF (5 min) & $74.0 \pm 4.76$ & $3.65 \pm 0.09$ & $11.26 \pm 0.11$ & $8.85 \pm 0.44$ & $978.40 \pm 35.15$ & $0.650 \pm 0.05$ & $22.45 \pm 0.22$ \\
PMF (6 min) & $61.0 \pm 4.43$ & $3.19 \pm 0.19$ & $8.83 \pm 0.96$ & $8.65 \pm 0.56$ & $836.29 \pm 113.37$ & $0.520 \pm 0.01$ & $22.43 \pm 1.25$ \\
Control & $68.0 \pm 3.26$ & $3.00 \pm 0.09$ & $9.51 \pm 0.51$ & $7.84 \pm 0.63$ & $849.54 \pm 6.44$ & $0.530 \pm 0.04$ & $22.02 \pm 0.34$ \\
LSD (P $<0.05)$ & NS & 0.508 & NS & NS & NS & 0.105 & NS \\
\hline
\end{tabular}

thresholds in that oxidative window were maintained through the antioxidative enzyme system.

\section{Antioxidant enzyme activity in germinating seeds}

\section{Superoxide dismutase (SOD) activity and catalase (CAT) activity}

Superoxide dismutase activity (SOD) increased linearly with time in all the treatments although the increment was higher in PMF magneto-primed seeds than SMF treated seeds. SMF primed seeds showed sudden increase in SOD activity after $12 \mathrm{~h}$ compared to unprimed control. The activity levelled off in unprimed control after $12 \mathrm{~h}$ of imbibition (Fig. 2A). Increase in SOD activity in static and pulsed primed seeds is important for conversion of $\mathrm{O}_{2}^{--}$to $\mathrm{H}_{2} \mathrm{O}_{2}$. Catalase activity decreased with time in SMF and PMF magneto-primed seeds and the decline was very steep in PMF treated seeds in the first $8 \mathrm{~h}$ but the activity doubled at $12 \mathrm{~h}$ of imbibition (Fig. 2B). Catalase dismutates $\mathrm{H}_{2} \mathrm{O}_{2}$ to water and oxygen but was observed to decrease in all treatments uptil $8 \mathrm{~h}$ of imbibition. The dynamics of CAT activity suggests that CAT did not play a major role in the early breakdown of $\mathrm{H}_{2} \mathrm{O}_{2}$, although primed seeds had higher activity than unprimed control.

\section{Peroxidase (POX), ascorbate peroxidase (APOX) and glutathione reductase (GR) activity}

Magneto-primed seeds showed higher peroxidase activity during germination than the unprimed control (Fig. 3A). SMF treated seeds showed intermediate activity amongst the three treatments throughout the germination process. PMF treated seeds showed $40 \%$ increase in the first $8 \mathrm{~h}$ of imbibition, followed by $75 \%$ at $12 \mathrm{~h}$ compared to unprimed control. Static and pulsed magneto-primed seeds had higher ascorbate peroxidase activity than unprimed seeds uptil $12 \mathrm{~h}$ of imbibition (Fig. 3B). SMF treated seeds had 60-70\% more activity than control seeds during the germination process. GR activity also declined till 8 and $12 \mathrm{~h}$ in SMF and PMF seeds, respectively (Fig. 3C). Greater decline in glutathione reductase (GR) activity was observed at $12 \mathrm{~h}$ in PMF (38\%) and $24 \mathrm{~h}$ in SMF (36 \%) primed seeds compared to unprimed control. Peroxidase reduces $\mathrm{H}_{2} \mathrm{O}_{2}$ to water using various substrates as electron donors. This was clear from increased activity of ascorbate peroxidase activity at the early stage of imbibition in seeds primed with static field indicating that ascorbate is used as substrate during early stages of free radical scavenging in SMF treated seeds. APX mediated $\mathrm{H}_{2} \mathrm{O}_{2}$ catalysis is dependent on ascorbic acid (AsA) - reduced glutathione (GSH) cycle. Ascorbic acid serves as electron donor to 

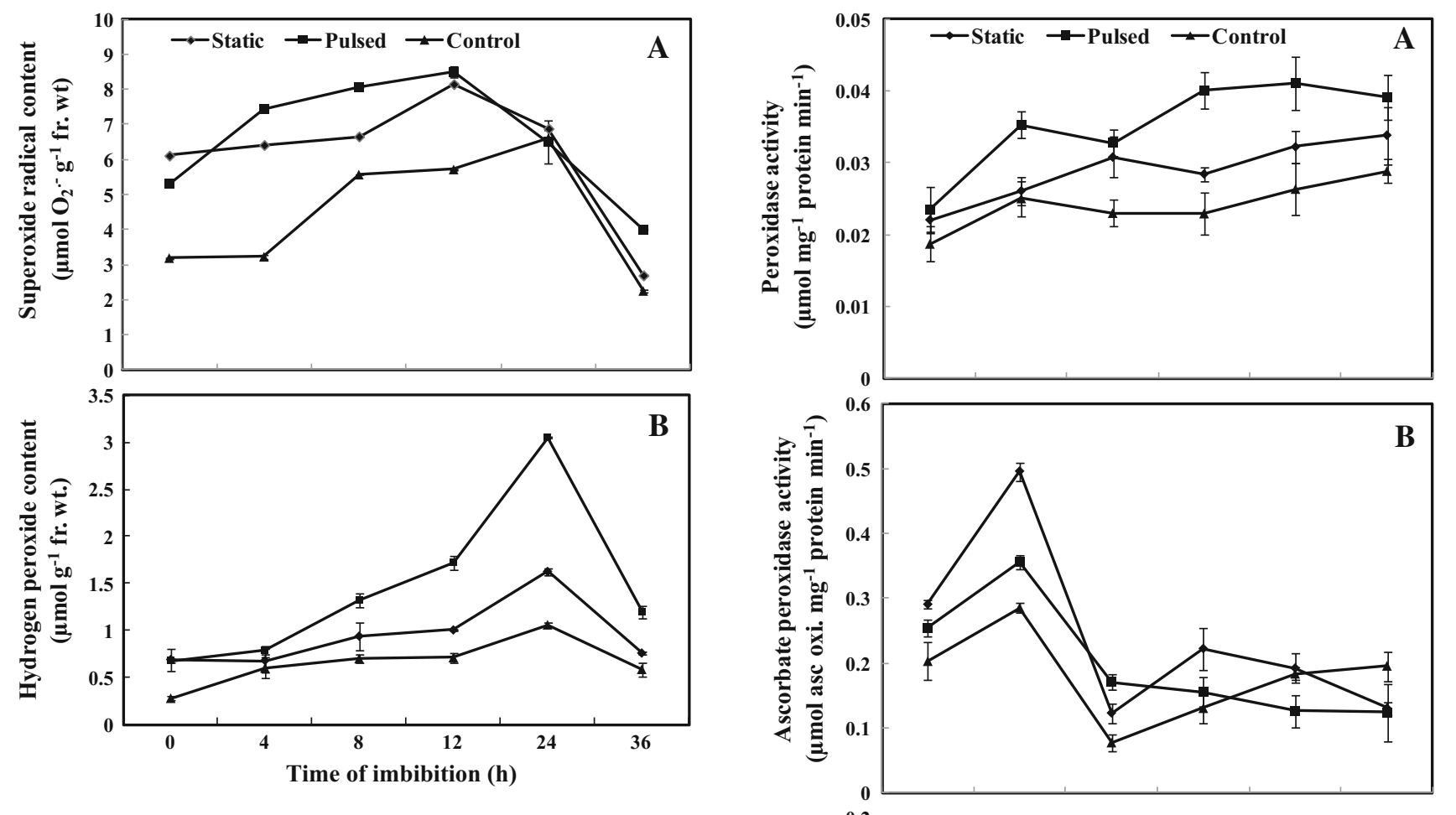

Fig. 1 Effect of magneto-priming on production of $\mathbf{A}$ superoxide radical and $\mathbf{B}$ hydrogen peroxide content in germinating cherry tomato seeds

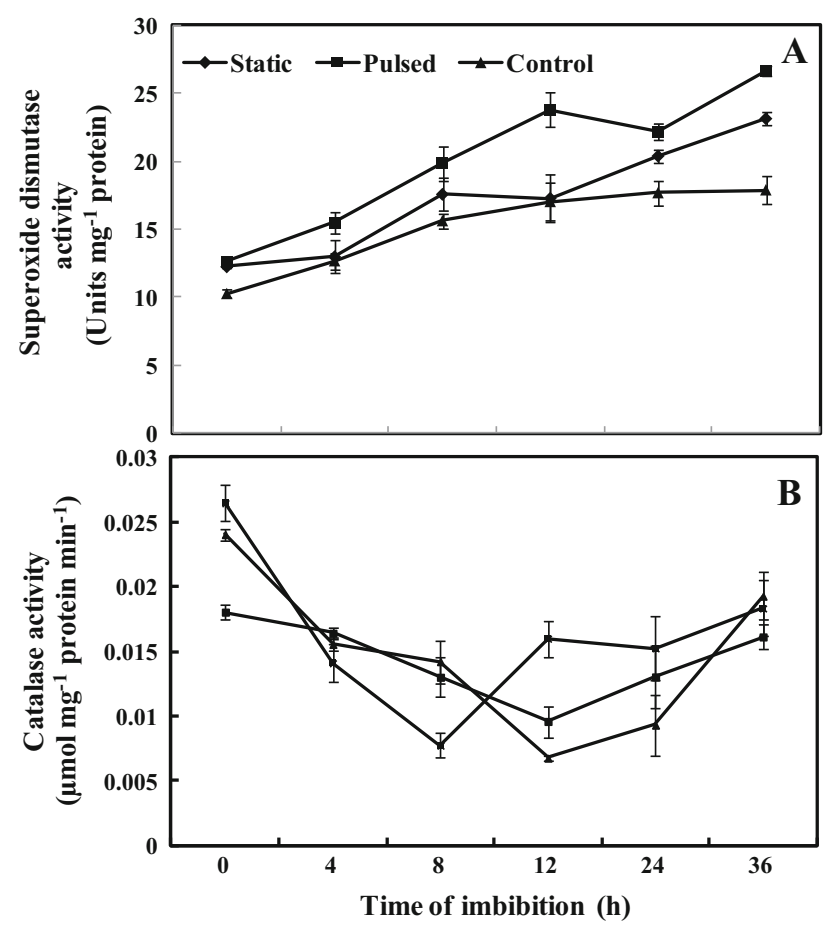

Fig. 2 Effect of magneto-priming on $\mathbf{A}$ superoxide dismutase and B catalase activity in germinating cherry tomato seeds

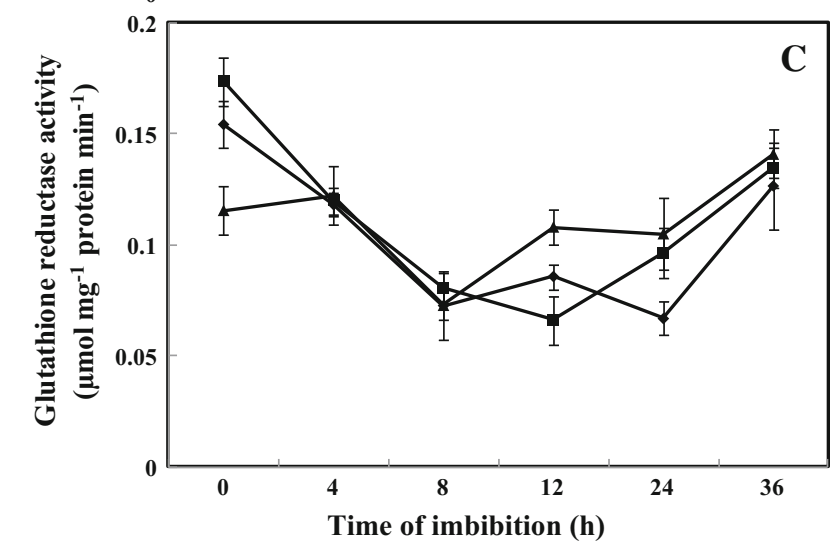

Fig. 3 Effect of magneto-priming on A peroxidase, B ascorbate peroxidase and $\mathbf{C}$ glutathione reductase activity in germinating cherry tomato seeds

activate $\mathrm{H}_{2} \mathrm{O}_{2}$ degradation by APX and GSH and enzymes such as GR, dehydroascorbate reductase, monohydroascorbate reductase are responsible for AsA regeneration. A decline in GR activity in primed seeds impaired the production of AsA, resulting in reduced APX activity at later stages of germination. There are several other enzymes that produce $\mathrm{H}_{2} \mathrm{O}_{2}$ (or active intermediates) in plants like peroxidases, oxalate oxidase, xanthine oxidase, membrane linked NADPH oxidase and amine oxidase (Bolwell and Wojtaszek 1997), among which cell wall peroxidase plays a major role in the generation of $\mathrm{H}_{2} \mathrm{O}_{2}$. 
Table 3 Yield and quality of cherry tomato from plants magneto-primed with static and pulsed magnetic field

\begin{tabular}{|c|c|c|c|c|c|c|c|}
\hline Treatment & $\begin{array}{l}\text { Average no. of } \\
\text { fruits plant } \\
\end{array}$ & $\begin{array}{l}\text { Average yield of } \\
\text { fruits }(\mathrm{kg} \text { plant }\end{array}$ & $\begin{array}{l}\text { Average no. } \\
\text { of fruits } \mathrm{m}^{-2}\end{array}$ & $\begin{array}{l}\text { Average yield } \\
\left(\mathrm{kg} \mathrm{m}^{-2}\right)\end{array}$ & $\begin{array}{l}\text { Average } \\
\text { weight }(g \\
\left.\text { fruit }^{-1}\right)\end{array}$ & $\begin{array}{l}\text { Lycopene content } \\
{\left[\mathrm{mg}(100 \mathrm{~g})^{-1}\right.} \\
\text { sample }]\end{array}$ & $\begin{array}{l}\text { Total soluble } \\
\text { solids }\end{array}$ \\
\hline Control & $197.2 \pm 31.9$ & $1.183 \pm 0.076$ & $788.8 \pm 127.8$ & $4.730 \pm 0.305$ & $6.40 \pm 0.40$ & $2.74 \pm 0.009$ & $10.00 \pm 0.0$ \\
\hline $\begin{array}{l}\text { SMF } \\
\quad(100 \mathrm{mT}, \\
30 \mathrm{~min})\end{array}$ & $180.4 \pm 10.3$ & $1.391 \pm 0.059$ & $721.7 \pm 41.3$ & $5.562 \pm 0.237$ & $7.76 \pm 0.53$ & $3.70 \pm 0.124$ & $11.00 \pm 0.0$ \\
\hline $\begin{array}{l}\text { PMF } \\
\quad(3 \text { min })\end{array}$ & $176.4 \pm 10.2$ & $1.503 \pm 0.124$ & $705.5 \pm 41.0$ & $6.012 \pm 0.495$ & $8.55 \pm 0.51$ & $6.75 \pm 1.0$ & $12.17 \pm 0.17$ \\
\hline $\begin{array}{l}\text { LSD } \\
\qquad(\mathrm{P}<0.05)\end{array}$ & NS & 0.217 & NS & 0.869 & 1.7 & 2.068 & 0.339 \\
\hline
\end{tabular}

Data are means of 3 replicate \pm SE. For yield each replicate consisted of eight plants

Peroxidase is one of the key enzymes during the life cycle of plant, and its role can be antagonostic depending on the site of production and developmental stage of plant. Cytosolic peroxidase (compound I) is involved in the consumption of $\mathrm{H}_{2} \mathrm{O}_{2}$, whereas cell wall peroxidase (compound III) secreted in cell wall and surrounding medium is involved in the release of ROS (Passardi et al. 2004).

Our study showed a very significant increase in non specific peroxidase activity in PMF and SMF magnetoprimed seeds. During the oxidative cycle of peroxidase, $\mathrm{O}_{2}{ }^{--}$is converted to $\mathrm{H}_{2} \mathrm{O}_{2}$ by extracting electron from an electron donor (Liszkay et al. 2003), i.e., NAD reduces $\mathrm{O}_{2}$ to $\mathrm{O}_{2}{ }^{--}$that can be converted to $\mathrm{H}_{2} \mathrm{O}_{2}$ by oxidizing extra NADH to NAD.

Seed invigoration brought about by SMF and PMF exposure of the seeds can lead to enhancement of growth of plants during the vegetative phase. This may lead to early commencement of reproductive phase in vegetable crops as also reported in cucumber (Bhardwaj et al. 2012). Dayal and Singh (1986) observed an increase in height and number of primary branches when tomato seeds were exposed to MF varying from 15 to $155 \mathrm{mT}$. There was increase in number of secondary branches and yield in safflower (Faqenabi et al. 2009) and broad bean (Podlesny et al. 2005) after treatment with MF.

Similar to previous reports on crop yields in case of MF treated seeds, our study also showed an increase in yield of 17 and $27 \%$ in plants from SMF and PMF treated seeds, respectively. Increase in yield in tomato exposed to fullwave rectified sinusoidal non-uniform MFs induced by an electromagnet at $100 \mathrm{mT}$ for $10 \mathrm{~min}$ and at $170 \mathrm{mT}$ for 3 min has been reported by De Souza et al. (2006). The earliness in flowering and fruit setting observed in magneto-primed seeds can be exploited for the benefit of farmers as it can fetch a good market value for the seasonal horticultural crops by supplying fruits early.
Flowering and fruiting were advanced by 7-9 days in magneto-primed plants than the unprimed control. Non-significant difference was found between fruit number amongst the different treatments. Average yield per square meter was 17 and $27 \%$ higher in plants from SMF and PMF treated seeds, respectively in comparison to control seeds. Average fruit weight was $6.4 \mathrm{~g}$ in control as compared to 7.76 and $8.55 \mathrm{~g}$ in crop raised from seeds treated with SMF and PMF, respectively. Fruit quality parameters like lycopene and total soluble solid (TSS) also improved in fruits of plants from treated seeds. Lycopene content increased by 1.3 and 2.4 -fold and TSS by 10 and $21 \%$ in SMF and PMF treatments, respectively in comparison to control (Table 3). Our study evinced that PMF treatment of cherry tomato seeds could be used as a remunerative and eco-friendly seed enhancement technology for yield improvement of cherry tomatoes.

Acknowledgments MKG thanks ICAR for Junior Research Fellowship to conduct this work. The authors also thank Head, Division of Plant Physiology for providing the facilities to conduct the experiments. The work was funded by I.A.R.I.

\section{References}

Abdul-Baki, A. A., \& Anderson, J. D. (1973). Vigour determination in soybean by multiple criteria. Crop Science, 10, 31-34.

Aebi, H. (1984). Catalase in vitro. Methods in Enzymology, 105, $121-126$.

Bailly, C., El-Maarouf-Bouteau, H., \& Corbineau, F. (2008). From intracellular signaling networks to cell death: The dual role of reactive oxygen species in seed physiology. Comptes Rendus Biologies, 331, 806-814.

Barba-Espin, G., Diaz-Vivancos, P., Job, D., Belghazi, M., Job, C., \& Hernandez, J. A. (2011). Understanding the role of $\mathrm{H}_{2} \mathrm{O}_{2}$ during pea seeds germination: A combined proteomic and hormone profiling approach. Plant Cell Environment, 34, 1907-1919.

Bhardwaj, J., Anand, A., \& Nagarajan, S. (2012). Biochemical and biophysical changes associated with magneto-priming in germinating cucumber seeds. Plant Physiology and Biochemistry, 57, $67-73$. 
Bilalis, D. J., Katsenios, N., Efthimiadou, A., Karkanis, A., Khah, M. E., \& Mitsis, T. (2013). Magnetic field pre-sowing treatment as an organic friendly technique to promote plant growth and chemical elements accumulation in early stages of cotton. Australian Journal of Crop Science, 7, 46-50.

Bolwell, G. P., \& Wojtaszek, P. (1997). Mechanisms for the generation of reactive oxygen species in plant defence-a broad perspective. Physiological and Molecular Plant Pathology, 51, $347-366$.

Chaitanya, K. S. K., \& Naithani, S. C. (1994). Role of superoxide, lipid peroxidation and superoxide dismutase in membrane perturbations during loss of viability in seeds of Shorea robusta (Gaertn. F.). New Phytologist, 126, 623-627.

Dayal, S., \& Singh, R. P. (1986). Effect of seed exposure to magnetic field on the height of tomato plants. Indian Journal of Agriculture Sciences, 56, 483-486.

De Souza, A., García, D., Sueiro, L., Gilart, F., Porras, E., \& Licea, L. (2006). Pre-sowing magnetic treatments of tomato seeds increase the growth and yield of plants. Bioelectromagnetics, 27, 247-257.

Dhindsa, R. S., Plumb-Dhindsa, P., \& Thorpe, T. A. (1981). Leaf senescence: Correlated with increased levels of membrane permeability and lipid peroxidation, and increased levels of superoxide dismutase and catalase. Journal of Experimental Botany, 32, 93-101.

Faqenabi, F., Tajbakhsh, M., Bernoosi, I., Saber-Rezaii, M., Tahri, F., Parvizi, S., et al. (2009). The effect of magnetic field on growth, development and yield of safflower and its comparison with other treatments. Research Journal of Biological Science, 4, 174-178.

International Seed Testing Association (ISTA). (1985). International rules for seed testing. Seed Science and Technology, 13, 299-513.

Liszkay, A., Kenk, B., \& Schopfer, P. (2003). Evidence for the involvement of cell wall peroxidase in the generation of hydroxyl radicals mediating extension growth. Planta, 217, 658-667.

Maguire, J. D. (1962). Speed of germination-aid in selection and evaluation for seedling emergence and vigour. Crop Science, 2, 176-177.
Mukherjee, S. P., \& Choudhari, M. A. (1983). Implications of water stress induced changes in the levels of endogenous ascorbic acid and $\mathrm{H}_{2} \mathrm{O}_{2}$ in Vigna seedlings. Journal of Plant Physiology, 58, $166-170$.

Nakano, Y., \& Asada, K. (1981). Hydrogen peroxide is scavenged by ascorbate peroxidase in spinach chloroplasts. Plant Cell Physiology, 22, 867-880.

Nakaune, M., Atsushi, H., Yong-Gen, Y., Matsukura, C., Yamaguchi, S., \& Hiroshi, E. (2012). Molecular and physiological dissection of enhanced seed germination using short-term low-concentration salt seed priming in tomato. Plant Physiology and Biochemistry, 52, 28-37.

Passardi, F., Penel, C., \& Dunand, C. (2004). Performing the paradoxical: How plant peroxidases modify the cell wall. Trends Plant Sciences, 9, 534-540.

Podlesny, J., Pietruszewski, S., \& Podlesna, A. (2005). Influence of magnetic stimulation of seeds on the formation of morphological features and yield of pea. International Agrophysics, 19, 1-8.

Radhakrishnan, R., \& Ranjithakumari, B. D. (2012). Pulsed magnetic field: A contemporary approach offers to enhance plant growth and yield of soybean. Plant Physiology and Biochemistry, 51, 139-144.

Rao, M. V., Paliyathm, G., \& Ormond, D. P. (1996). Ultraviolet-B and ozone induced biochemical changes in antioxidant enzymes in Arabidopsis thaliana. Plant Physiology, 110, 125-136.

Shine, M. B., Guruprasad, K. N., \& Anand, A. (2012). Effect of stationary magnetic field strengths of 150 and $200 \mathrm{mT}$ on reactive oxygen species production in soybean. Bioelectromagnetics, 33, 428-437.

Smith, I. K., Vierheller, T. L., \& Thorne, C. (1998). Assay of glutathione reductase in crude tissue homogenates using $5,5^{\prime}$ dithiobis. Analytical Biochemistry, 175.2, 408-413.

Thimmaiah, S. R. (1999). Pigments. In: Standard methods of biochemical analysis (pp. 306-307). New Delhi: Kalyani Publishers. 